\title{
Assam as a New Economic Space: Colonial Annexation in the Region and its Implications
}

Bandita Deka ${ }^{\dagger}$

\section{Abstract}

The current social and political processes of Assam in terms of demographic aspect and frontier area policies cannot be seen to be a development in isolation from British colonial policies. The entire system is linked to a historical process of ownership and inheritance. The British entry into the North-Eastern region of India, at the end of the Anglo-Burmese war, marked the beginning of colonial penetration with the consequence of unanticipated transformation of socio-economic and demographic profile in the region. The profound commercial significance of Assam explored by British colonialism led to the development of the Brahmaputra valley into a new economic space. Accordingly, the colonialists consolidated political interventions through the construction of frontier policies that created a divide between 'Hills' and 'Plains'. The policies of social and cultural subjugation, followed by the colonialists, brought the neighbouring hill tribes under colonial control, and the entire region was being turned into a politico-economic jurisdiction of colonial subjects. Such policies envisaged by the British with a commercial motive, however, anguished the ethnic strife- the existing social landscape, the economic space and the political set-up of the region. The current problem of foreigners' issue and the frontier issue is, in fact, the continuation of the colonial traditions. An understanding of the colonial pattern of exploitation of resources through social and political control would provide an apprehension of the past causes and present effect relationship. Hence, this study attempts to understand the implications of the colonial era political developments in Assam considering its economic potentiality that has given a whole new dimension to the entire regional set-up.

Keywords: Colonialism; Subjugation; Demography; Economic Space; Political Set-up; Assam

\footnotetext{
${ }^{+}$PhD Scholar, Department of Social Sciences (Economics) (OKDISCD), Dibrugarh University, Email: banditadeka8@gmail.com

(C) 2020 Deka. This is an Open Access article distributed under the terms of the Creative Commons Attribution License (http://creativecommons.org/licenses/by/2.0), which permits unrestricted use, distribution, and reproduction in any medium, provided the original work is properly cited.
} 


\section{Introduction}

The weaknesses of the Ahom Rule, in terms of, incompetence and inefficiency of the monarchs during its closing years gave the Burmese a favourable opportunity to interfere in the internal affairs of the kingdom. However, the Burmese invasion to the internal affairs ruined the country and their disturbance in the already British controlled areas led to the AngloBurmese war in 1824 and the war came to an end with the signing of the Treaty of Yandaboo in 1826, where the Burmese renounced their rights over Assam and Assam was formally annexed by the British. The political settlement of Assam following the British colonial penetration into the North-Eastern part of India after the Treaty of Yandaboo (1826), was initially meant to be a transitional arrangement. Nevertheless, once British colonialism explored the possibility of commercial crops like tea and also coal and oil in the region, they decided to establish the Brahmaputra valley as a direct colony of East-India company and integrate the region with the global market economy. The exploration of the profound economic and commercial significance of Assam led to the emergence of the region as a distinct economic space with political dimensions attached to it. The momentous economic prospect led to the colonial penetration in a way that initial influence got transformed into full political control, considerably changing the existing social and demographic set-up in the entire region. The importance of understanding these issues lies in the fact that the age-old agitation in Assam regarding conflicts around the illegal immigration problem along with the geopolitical issues cannot be worked out without interpreting these historical considerations. Therefore, there is a need to explicate the different dynamics associated with these issues, which will provide scope for arriving at effective negotiations.

The study begins with a theorisation of colonialism. Following this, it discusses the construction of colonial routes for resource frontier. The final sections discuss colonial expansion in Assam in ascertaining economic potentiality; creation of new economic space and consolidation of the frontier areas.

\section{Theorising Colonialism}

Sociologist Ronald J. Horvath (1972) considered colonialism as "a form of domination and exploitation. The idea of domination is closely related to the concept of power." According to Loomba (1998), colonialism refers to the conquest and control of other people's lands and goods with the forceful seizure of land and economy. Loomba (1998) further views it to be a process that restricts the original citizens, which creates complex relationships in human history. Thus, the phenomenon of colonialism generated a particular way of looking at the world. In this context, it is crucial to understand the process of colonisation which Pels (1997) calls to be a process of emergence of western governmentality. In Assam, the motivation was solely economic exploitation, and the convenient way of doing that was through gaining political power. It was admitted by Misra (1980) that despite having an abundant supply of raw materials in the state to run the major industries like Tea, Oil, Plywood etc., which were mostly 'extractive industries', the lack of investments by indigenous capital provided scope for British capitalists to undertake those. The author further argues that some of the characteristics of Assam's economy fit in exactly with the classical definition of 'colonialism'. By quoting E. F. Wakefield's argument regarding Britain's colonial policy that "an industrialised State could generate surplus capital which it was unprofitable to invest at home either in agriculture or in industry (because foreign markets did not expand fast enough to absorb its products). This capital would be more profitably employed if it were exported to places where fertile land was in good supply. Provided ample labour was made available by emigration, capital would be now more productive in these new lands and at the same time would expand the market for British manufactures and increase the supply of cheap food-stuffs and industrial raw materials", Misra (1980; pp: 1357-1364) 
recognised Assam to be a 'Colonial Hinterland' as in the same way, Assam became an ideal market for manufactured goods with products taken out of the state. This study discusses how, in order to consolidate economic control in the state, the British colonialism designed the entire pattern of resource exploitation by gaining political control in the state. In other words, this study aims to understand the British colonial expansion in Assam by developing the region as an economic space for running the accumulation economy and the implications of it in the polity of the region, thereby giving a whole new dimension to the entire system. It begins with a brief discussion of the significance of the study. It then critically discusses the findings-Assam as a new economic space. Following this, it illustrates the implications of British Colonial annexation.

\section{Significance of the Study}

The economic, social and political processes of Assam at the present times in terms of demographic aspect and frontier area policies cannot be seen to be a development in isolation from British colonial policies. The entire system gets linked to a historical process of ownership and inheritance having an economic aspect being associated with it. Viewing the current phase by overlooking the historical context of it would undermine the linkage between the present and the past. What is essential here is to understand the fact that the designing of the policy frameworks was such that economic forces tend to regulate the political processes and the policy developments of the present are in fact the manifestations of the processes of the past. It is in this context that the colonial penetration into the region needs to be analysed considering its economic potentiality and strategic location. The study is analytical in nature purely based on secondary sourcesbooks, articles and research publications are being consulted for analysing the proposed objective.

\section{Discussion}

\section{Construction of Colonial Routes for a Resource Frontier}

The comprehension of the processes of colonial annexation of Assam first requires an understanding of the colonial era construction of the distinct geographical terrains: 'Hills' and 'Plains'. The pre-colonial history of the NorthEastern region presents a picture of the hills in the spaces between the plains. The hills had very small village like organisations having some sort of political formations and the states emerged as institutions in the plains. So, before colonial annexation, the present North-East can be divided into:

State-space, that is, space which experienced emergence and growth of state or consolidation of the state as an institution and

\section{Non-state space, that is, the hills.}

In the plains, it was the particular production system, settled cultivation that led to agrarian surplus based on which state could emerge, grow and consolidate itself. However, in sharp contrast to the plains, the system of production in the hills was shifting mode of cultivation with no surplus left that could lead to the emergence of a state. The political and cultural organisation of the hills were being described as non-state space by the Britishers being interpreted in the perspective of 'illegal space' as against the state lowlands (Baruah, 2002). With the required expectation in terms of economic and political expansion, it became very much essential for the colonisers to consolidate the already constructed, but the fluid image of the hills and the plains and as such frontier policies were adopted leading to an entirely new hill-plain relation. Sir Robert Reid, the Governor of Assam (4th March 1937 - 4thMay 1942), speaking in the Royal Society of Arts to the people living on the frontier regions of the Erstwhile British Assam province expressed his views that "neither racially, historically, culturally, nor linguistically have they any affinity with the people of the plains, or with the people of India proper. It is only by a historical accident and as a natural administrative convenience that they have been 
tacked on to an Indian province" (Reid, 1944; pp: 18-29). Thus, whether it was by 'historical accident', as Reid had termed it or by the impetus for colonial expansion, the region witnessed a drastic change following the Treaty of Yandaboo.

\section{Colonial Expansion in Assam}

While attempting to locate the importance of Assam's economy in a large global market economy, it is of utmost importance to understand the political-economic perspective of the British policy of expansion in the region. Although Ahom rule was to be restored after the conclusion of the Anglo-Burmese war, with the expulsion of the Burmese, the East-India company departed from its stand and became the de-facto ruler of Assam. Sir Edward Gait gave grounds for this policy change of the British authority arguing that earlier the Burmese, under their possession of the land, had overthrown the old administrative landmarks along with dividing people into different conflicting parties that created massive internal contradictions and political turmoil. If the territories are to be restored with new chiefs, it would have again caused civil wars due to fatal antagonism among the rulers (Gait, 1906). This is being termed as the British 'Expansionist Policy' with the argument that the British frontier policy had always been a moving phenomenon, which proved detrimental to the free and independent existence of the native Indian states (Kalita, 1992). Kalita (1992) gives reasons for the British interest in the areas lying to the North-East direction of Bengal Presidency that fuelled their expansionist policy. Firstly, the British quest for the need of a natural frontier. Secondly, British expansion to check Burmese territorial expansion and thirdly, ascertaining the resources of the province, causing permanent British annexation. Importantly, considering the whole issue from a lucrative trade perspective,

\footnotetext{
1 Posa is a kind of payment during the Ahom rule (introduced by Ahom King Pratap Singha) which was paid by the inhabitants of the foothill areas to the hill tribes to stop raids and seasonal attacks on them and normalize the Ahom-tribal relationship. Jha (1996: insert page number) defined Posa as "The Posa literally means a collection of
}

frontier areas were given a completely new dimension by drawing up new boundaries with colonial intervention. Lower Assam came permanently under the British dominion in 1828 when it was viewed as a huge revenuegenerating part, with an estimation of revenue of over three lakhs as against estimation of less than one lakh after reimbursing for royalty from upper Assam (Barpujari, 1963). In upper Assam, the revenue generation was on the earlier prevailing Khel system but by abolishing the Paik system and introducing a monetised revenue system.

The North-Eastern region was not shaped by the ideas of absolute state boundaries and the pursuit of firm boundaries mostly proved to be elusive in this part of the region (Zou and Kumar, 2011). The Ahom rule shared boundaries with most of the tribes that habituated in the vicinity of the region, in the plains as well as in the hills. The Ahom state boundary was fluid, and it regularly changed since its inception. The British who had replaced the Ahoms as the major power in the region after the Anglo-Burmese war were left to deal with a number of these tribes. However, most of the frontier policies followed by the British were supposedly the policies which were the legacy of the Ahoms. The system of Posa1 is one such policy that the British colonisers adopted from the Ahom period as a part of their dealings with a few of the frontier tribes. However, in most cases of the region, the state lines were re-drawn according to British aspirations which were "designed to suit their administrative convenience" (Leach, 1960; pp: 49-68).

\section{Ascertaining Economic Potentiality, Creation of New Economic Space and Consolidation of the Frontier Areas}

Although on the one hand, the colonial annexation in this territory was mostly due to imperial and strategic considerations, yet the

subscription for a common purpose. In general, the term Posa came to be applied to all payments made to the hill tribes by the Governments; whether these were in commutation of blackmail, compensation for customary demands of the tribal chiefs of the bordering hills of Arunachal Pradesh". Also see Mackenzie (1989; pp.7-8). 
factor, not to be considered insignificant, the quest for tea, being a highly lucrative commercial article, necessitated the annexation in full perspective (Gupta, 1959). Till then, only China used to produce tea as a trade article and China's trade policy, being a closed economy system, restricted its commercialisation by others. In view of the active contemplation of the possibilities of tea cultivation, the importance of this region increased highly and Gupta (1959) argued the Anglo-Burmese conflict of 1824-26 to be partly influenced by this economic consideration. Guha (1977) also argues that the scheme of colonisation was made all the more acceptable with the growing prospect of tea culture in Assam. The prospects of huge gains from tea necessitated the demand for land. The land became a commodity that was in high demand for extension of tea cultivation, and thus, land procurement became a virtual necessity to cope up with the demand for more land under cultivation. In view of the fact that the wasteland can contribute a lot in terms of resource gain if it is made available for cultivation, "Wasteland Settlement Rules" were framed in 1838 where vast land areas were brought under tea cultivation (Guha, 1977). In addition, the introduction of monetised revenue system by the British caused disposition of people who were unable to pay the land revenue in cash. This had the intention of bringing them to work in the emerging plantation sector. However, as a result of the unfavourable response from indigenous people, they were being claimed as indolent (Sharma, 2011). Hence, indentured labours were brought from other parts of colonial India to convert the Brahmaputra valley into a tea-producing belt (Jha, 1996). This way, the new plantation economy was wholly subjugated to the colonial hands with immigrant usury and foreign capital. Nevertheless, the expansion of tea sector in the plains led to inevitable conflict with the people in the hills as there was seizing of grazing fields and encroachment upon the Jhum rights of the tribal shifting cultivators (Guha, 1977).

The raids by the Nagas on the tea gardens along with the British protected villages intensified the British officials (Das, 2018). The attack from the hill people in the surrounding of the newly developed tea sector created a different kind of relation between the hill people and the nonindigenous plain people. So, British colonialism, in order to protect the plains for their own interest, introduced the "Bengal Eastern Frontier Regulation, 1873" or in popular term the "Inner Line Permit'. The line system segregated the hills from the plains restricting the free movement of the people. The Inner Line Regulations were set about trying to demarcate the boundaries of "British India" from the "tribal areas". Sarmah (2016) claims it to be the colonial creation of dichotomy between the hills (being interpreted as 'primitive and savage') and valleys (being interpreted as the 'civilised') as segregation of hills was necessary for the integration of the plains for creating colonial subjectivity. These regulations introduced the system of drawing an imagined boundary to protect the British subjects and was supposed to demarcate the tribal areas from Assam proper. However, they were made to appear as an administrative set up to protect the hills as well as the people in the plains.

Meanwhile, the discovery of existence of the oil, coal and other minerals in the upper Assam area, being the most thriving commodities, further precipitated the colonial influence in the region to a great extent. International capital was also attracted by the exploration of petroleum which became an integral part of the petroleum economy at the global scale, thereby considerably enhancing the British imperial economy (Saikia, 2011). The scope of imperialism took firm shape with British capital and enterprise commercialising the geological exploration in the eastern part of Assam (Saikia, 2011).

\section{Implications of British Colonial Annexation}

There are many implications of colonial annexation in Assam. The phase of Assam's economy from the period 1826 to 1873 was a period of transition with the closed society being opened to the global market through tea culture leading to the migration and settling of required labour and capital, accomplishing infrastructure, skills, ideas and thus exposing the region for a 
capitalistic set-up. The progress and development envisaged by the British with a commercial motive being attached to it, however, anguished the ethnic strife, the existing social landscape, the economic space and the political set-up of the region and the fatal consequences of all these are being followed up even today.

\section{First Phase of Demographic Transition}

With the subsequent discovery of tea cultivation in Assam and the despise of the natives to work as labourers, there arose the question of labour supply, and the British administration decided to procure labourer from outside Assam. This marked the beginning of demographic watershed ever in the history of Assam. The first phase of demographic transition, thus, happened with the people from central parts of colonial India migrating to Assam to work in the plantation sector. The migrant labours from other provinces settled down in the tea estates of Assam. With the growth of the plantation sector, Assam was prepared for meaningful economic exploitation through trading and banking services, with a congregation of bankers and traders from other Indian provinces coming to Assam as local business awareness in the region was entirely restricted at that time (Guha, 1977). This led to increased flow of migration to the Brahmaputra valley with an estimated increase of population from one million in 1826 to about two million in 1872 with the ramification of growth of not the overall but only the British owned and managed sectors (Guha, 1977). Thus, there was a significant demographic change as these people assimilated with the Assamese culture becoming an essential part of it and this separate class of population gave a new dimension to the overall population structure (Sonowal, 2018).

\section{Creating Division between Hills and Plains}

Another implication of colonial annexation in the region was the creation of the inner line dividing the hills from the plains. Zou and Kumar (2011), while talking about the importance of implications of surveys and map-making in shaping the boundaries of the region, claimed that the hill societies of the region in the North-
Eastern part of India had a rich oral tradition of 'cosmography'. Their interpretation was based on their own beliefs, and the creation of chiefdoms all adhered to the idea of "chiefs ruling over people bounded by patrimonial loyalties and not over land which was a free gift of nature" (Zou and Kumar, 2011). Their idea of cosmography was reflected in their idea of rule over the land, which was vertical in nature as it stemmed from the idea of clan-based 'divine' origin. This was in sharp contrast to the British way of construction of maps, which were horizontal in nature as it spread overland on the earth's surface. The idea of the construction of British maps was bounded territories, which were delimited by the concept of their own understanding of the idea of state and nation.

Acharyya (1996) observed how the tribal policies regulated by the Ahoms were very realistic and judicious, where Ahom policies in relation to its neighbours in the hills paint a picture of success in larger portions of their rule with the following of appeasement policy for other tribes whenever necessary. Although there were occasional breaks in forms of punitive measures being taken to punish guilty parties for raids in a broader context, the policies brought out the successful side of the Ahom frontier policy. Luthra (1971) also shares a similar stand by viewing the Ahom policy towards the tribal as successful with achieving 'reconciliation with certain tribes' and 'assimilation' of other tribes. With the demise of the Ahom state and the British focusing on the consolidation of their rule, these tribes enjoyed for a while 'noninterference' from the plains. The British followed the policy of non-interference in earlier stages of its consolidation. On the whole, the posa system initiated by the Ahoms worked for the British also in maintaining relations with the tribes. However, the relation was not always peaceful as there were from time to time raids on the plains and its people. The people of the plains adjoining the hills were now British subjects. The British need for growing cultivation and production of surplus necessitated the protection of their interest. Punitive measures were taken in retaliation of the raids. Level of retaliation also increased compared to the 
Ahoms action. Raids on plains were followed by burning of whole villages in the hills where the instigators resided or belonged.

Das (2018) has talked about how the Inner Line was a political rather than a protective tool introduced by the colonial government in North East India. He takes the case study of the 'Sibsagar frontier' and how through various official 'grants', 'correspondence' and 'leases' has tried to paint the picture of the line benefitting the subjects therein, while in actual practice, the benefit was only for the colonisers and not their subjects. He begins by looking into the relations between the Ahoms and the Naga tribes and finds the mutual co-operation of them in keeping the boundary very natural and flexible and thereby maintaining friendly relations. These un-administered lands in the plains near the foothills of the Naga Hills, which were claimed by the Naga chiefs as ancestral lands upon which they did shifting cultivation and sometimes had very nominal settlements, became a great source of contention during the British time, not only for the tea planters for extension of their plantations but also for developing the mining industry (Das, 2018).

The British used the Inner Line to conjure up the necessary directives to bring these lands under their administrative domain or to declare them as 'Reserve Forest' thereby severely limiting or in most cases completely ending the claims of ownership on these lands and resources therein for the Naga tribes. Snippets of official correspondence of the British officials shows how specific recommendations were made by British officials completely favouring their own interest in bringing in territories which were outside the sphere of the Inner Line from time to time (Das, 2018).

There was also an attempt to define an outer line along with the inner line. It became necessary to draw a line up to which colonial work was intended which was indefinite (Nath, 2014). The Outer line being merely an imaginary line, was not available as the demarcation process, since its length and its distance varied from the Inner Line. Nevertheless, such kind of definition also came under contestation, as the Outer Line was merely an imaginary boundary with the purpose of extending the Inner Line as and when desired. Nath (2014; pp: 409-419) believes that it was the British policy of "introducing loose administration in the area between the Inner Line and the Outer Lines with a view of further penetration".

\section{Colonial Annexation of the Hills}

Initially, the aim of British colonialism was not to make any intervention in the hill areas (which were considered as a subtle buffer) as they concentrated mostly in revenue generating areas, mainly where land revenue was to be obtained in the form of cash. However, protecting the colonial interest in the plains required the annexation of the contiguous hill areas, thereby bringing them under Assam province and substantially expanding the territory of Assam along with establishing political dominion over the hill tribes by organising the hills in the form of administrative districts (Sarmah, 2016). The policy of dealing with the hill tribes also changed with the colonisers making an intervention in the hills, controlling the hill societies by coercion and making the people subservient to colonial regimes through compromise. Numerous police outposts were opened up near the hill territories. Any incidence of raids or killing of the people of the plains was retaliated by the use of these outposts to punish the guilty. The British policies in dealing with the tribes of the hills in comparison to the Ahoms were claimed to be much firmer policies (Luthra, 1971). A definite outlook of the Ahom policy in relation to the hill societies was the preservation of peace and putting an end to the raids. The posa system allowed them to maintain cordial relations with the tribes residing in the hills. The idea of annexation of these areas was not devised to be a necessary step. Ahom expansion was only limited to the Brahmaputra valley, and therefore, the only expansion that became observable throughout their rule was its westward expansion. However, as the British expanded into the territories of the regions to the Northeast of Bengal, there emerged the necessity to protect its interest and investment 
in the region. The constant raids from the hill tribes were a threat to the British. Unlike the Ahoms, the British had the political aim of extending their dominion over the tribal people (Luthra, 1971) and this kind of extension of dominion was not necessarily conquest of these regions per se but the necessity to bring them under British sway of control.

\section{Second Phase of Demographic Transition}

A new chapter was opened in Assam's history by colonialism with migration playing an integral part. Contemporary to the migration of the teagarden labours, there was a large-scale influx of immigrants from the then erstwhile East Bengal. Having a large number of people being engaged in the non-agricultural sector (tea, oil and coal) and with the increasing number of labours requiring more food grains, a kind of imbalance was created in the production of food as Assam's farming structure was unable to provide that. To meet the crisis, by 1872, food was to be imported from other parts of India (Kar, 2012). The availability of vast land area in the western part of Assam was not conducive for tea cultivation but were conducive for wet rice cultivation. Where, on the one hand, the government was not making any immediate plan for bringing these valuable land areas under cultivation, on the other, there was a rapid increase in population in Bengal, the cultivators not being able even to sustain their families there.

Moreover, the British rule already made provisions of land classification with the introduction of the line system, and the categorisations were: a) land in which migrants might settle freely; b) land in which migrants could not settle and c) land where the line was drawn, migrants can settle on one side of it (Borthakur and Thaosen, 2012). Thus, to bring those fallow lands under cultivation with this colonisation scheme, a whole different process of 'Peasantrisation' was started where people were brought from East Bengal part of colonial India, and they were settled on the cultivable wastelands of Assam. Consequently, food production process encouraged another phase of migration, causing demographic change in
Assam over time. Although the continuous inflow of migrants from East Bengal fuelled the already existing apprehension of consciousness about the linguistic and ethnic identity of 'being Assamese' among the upper-middle-class indigenous people, yet politically there was no resistance to this migration by the nationalist leadership and as such Assam's demographic map has changed considerably (Dass, 1980). The author calls it 'Assamisation' of Bengali Muslim migrant peasants with the system of land-wage contract, making them the proprietors.

\section{Conclusion}

British colonial penetration into the NorthEastern part of India with the policy of intervention in the frontier areas was necessitated entirely by their economic and political interest. Therefore, the entire transition and development in the region needs to be viewed in the critical context of a political economy perspective. The political system at that time was build up in a way to protect and safeguard the exploitation of the economic potential, and it did not at all cover the betterment of the local society. Maintaining a strict boundary was their necessity to protect their interests and not protecting any hill/plain people's way of life. In the name of noninterference, a political boundary was drawn up without any consultation of the natives. This had significant implications as the boundaries drawn by the British were adapted by the post-colonial state as rigid boundaries and therein lays the political and economic boundary conflict that we see today.

Moreover, it ultimately took a huge time for the people to realise the costs of all those interpretations. Conversion of the Brahmaputra valley into a market economy was, in a sense, perilous where the fate of a local economy was tied to an uncertain global market (Sharma et al., 2012). The annexation of the hills one after another, following the annexation of the Brahmaputra valley led to the emergence of the region politically as an administrative space under the British rule. Accordingly, by 1930s, the defined zone of Assam with the Brahmaputra valley surrounded by the hills had a new social 
set-up, significantly different demographic composition, new economic consideration and a completely new hill-plain relation.

\section{References}

Acharyya, N. N. (1996). A Brief History of Assam. New Delhi: Omsons Publications.

Barpujari, H. K. (1963). Assam in the Days of the Company, 1826-1858: A Critical and Comprehensive History of Assam During the Rule of the Est-India Company from 1826-1858. Guwahati: Lawyer's Book Stall.

Baruah, S. (2002). Gulliver's troubles: State and militants in North-East India. Economic and Political Weekly, 37(41), 4178-4182. DOI: 10.2307/4412711

Borthakur, A. and Thaosen, R. (2012). Rethinking the line system in Assam and its politics. Proceedings of the Indian History Congress, 73, 545-552.

Das, D. (2018). Colonial construction of a frontier: Debating the Inner Line Regulation in Sibsagar-Naga Hills. Economic and Political Weekly, 53(7), 52-61.

Dass, S. K. (1980). Immigration and demographic transformation of Assam, 18911981. Economic and Political Weekly, 15(19), 850-859.

Gait, E. (1906). A History of Assam. Calcutta: Thacker, Sprink and Co.

Guha, A. (1977). Planter-Raj to Swaraj: Freedom Struggle and Electoral Politics in Assam 18261947. New Delhi: People's Publishing House.

Gupta, H. L. (1959). An unknown factor in the annexation of Assam. Proceedings of the Indian History Congress, 22, 412-418.

Horvath, R. J. (1972). A definition of colonialism. Current Anthropology, 13(1), 46.

Jha, B. N. (1996). Politics of Posa: A case study of pre and post-independence scenario in Arunachal Pradesh and Assam. Proceedings of the Indian History Congress, 57, 446-458. Kalita, R. C. (1992). Assam in the $18^{\text {th }}$ Century. New Delhi: Omsons Publications.
Kar, B. (2012). British colonial policy of immigration in Assam (1826-1910).

Pratidhwani- A Journal of Humanities and Social Science, 1(2), 219-222.

Leach, E. R. (1960). The frontiers of Burma. Comparative Studies in Society and History, 3(1), 49-68. DOI:

https://doi.org/10.1017/S0010417500000992

Loomba, A. (1998). Colonialism/Postcolonialism. London, England: Routledge.

Luthra, P. (1971). North-East frontier agency tribes: Impact of Ahom and British policy. Economic and Political Weekly, 6(23), 11431149.

Mackenzie, A. (1989). The North-East Frontier of India. Delhi: Mittal Publications.

Misra, T. (1980). Assam: A colonial hinterland. Economic and Political Weekly, 15(32), 13571359+1361-1364. Nath, J. (2014). Anglo-Abor Treaty 1862 and its Significance in Relation to the Inner Line Regulation, 1873 and Arunachal History. Shillong: Singhania Publishers.

Pels, P. (1997). The anthropology of colonialism: Culture, history, and the emergence of western governmentality. Annual Review of Anthropology, 26, 163-183. http://doi.org/10.1146/annurev.anthro.26.1.16 3

Reid, R. (1944). The excluded areas of Assam. The Geographical Journal, 103(1/2), 18-29.

Saikia, A. (2011). Imperialism, geology and Assam petroleum: History of oil in colonial Assam. Economic and Political Weekly, 46(12), 48-55.

Sarmah, B. (2016). The cauldron of conflict: Politics of peace, governance and development in India's North-East. Social Scientist, 44(11/12), 15-36.

Sharma, J. (2011). Empire's Garden: Assam and the Making of Modern India. Durham: Duke University Press.

Sharma, N., Madhusudan, M. D. and Sinha, A. (2012). Socio-economic drivers of forest cover change in Assam: A historical perspective. Economic and Political Weekly, 47(5), 64-72. 
Sonowal, B. (2018). Immigration in Assam during colonial rule: Its impact on the socioeconomic and demography of Assam.

International Journal of Innovative Studies in Sociology and Humanities, 3(2), 10-14.
Zou, D. V. and Kumar, M. S. (2011). Mapping a colonial Borderland: Objectifying the geo-body of India's North-East. The Journal of Asian Studies, 70(1), 141-170.

DOI: https://doi.org/10.1017/S0021911810002 986 